\title{
FORMATION OF RESOURCE-SAVING STRATEGY FOR THE DEVELOPMENT OF THE AGRO-INDUSTRIAL COMPLEX
}

\begin{abstract}
The article is dedicated to the development and justification of the theoretical and conceptual grounds and methodological toolkit for the resource-saving strategy for agro-industrial complex development under the set priorities of national economy development and the preconditions for establishing favorable entrepreneurial climate in the agrarian sector of national economy.

Key trends and development factors are outlined for the process of economic regulation of agriculture intensification, the structure and the dynamics of resource provision indicators in agriculture; the author also outlines the contradictions, directions and factors in increasing the efficiency of agriculture functioning within the agro-industrial complex of Ukraine.

Conceptual grounds are formulated for the integration system mechanisms for agro-industry development, also presented comprehensive long-term development strategy on agricultural resource-saving, which already gave its results on selected enterprises of Poltava region.
\end{abstract}

Keywords: agro-industrial complex; resource saving; resource-saving mode in agro-industrial complex; strategy of resource-efficiency of the agro-industrial complex.

\section{INTRODUCTION}

The effectiveness of resource-saving in agrarian and processing production is inextricably related to the use of innovative methods, technologies, means of labor. The need to solve theoretical and practical problems aimed at identifying and using the reserves of efficiency growth of agro-industrial enterprises by reducing the resource intensity of production determined the relevance of the problem under study. The development of a holistic scientific concept for the formation of a system for regulating the resource-saving development of the agro-industrial complex is an urgent scientific problem, the solution of which will allow to differentiate the emphasis in the use of regulatory mechanisms for effective use of resources and means of labor, and determine the objectives and nature of innovative resource-saving development of the agro-industrial complex.

\footnotetext{
${ }^{1}$ Nataliia Gerasymchuk, PhD, Department of Economics, Faculty of Management, Rzeszow University of Technology, al. Powstańców Warszawy 12, 35-959 Rzeszów; e-mail: n.gerasymchu@ @rz. edu.pl. ORCID: 0000-0002-3931-5320.
} 


\section{THE OBJECT OF RESEARCH}

The author investigates the solution of the scientific problem of the formation of a resource-saving strategy in the agro-industrial complex to ensure the systemic action of the components of an active resource-saving policy aimed at overcoming the inertia of perception by national agricultural producers of the influence of driving forces on the part of the continental and world agrarian and processing spaces, which, unlike existing approaches, to find out the readiness of domestic agro-industrial complex to use the best experience of application an innovative chain of effective resource conservation and resource use.

\section{THE AIM AND OBJECTIVES OF RESEARCH}

The aim of research is substantiation of the features of development and presentation of examples of the implementation of the resource-saving strategy in the agro-industrial complex by the example of agricultural enterprises in Semenivka, Globyno and Novosanzhary districts of the Poltava region.

According to a specific aim, the following problems are consistently solved in the research:

1. A steady growth of the final results of the functioning of the country's agro-industrial complex.

2. An implementation of the main directions of ensuring the country's food security on the basis of strengthening the positions of domestic agricultural enterprises in international, national and regional food markets.

3. The use of the provisions of integrative mechanisms of the resource saving strategy in the agro-industrial complex as an attractor of the intensification of agro-industrial production by optimizing the processes of resource use and resource efficiency in the form of interactive use of new progressive forms of organization of agricultural production and processing of agricultural products.

4. Research of existing solutions of the problem Various aspects of the resource-saving strategy were studied by leading domestic and foreign scientists.

The first and most significant author, opened the topic of resource saving, was the former president of Kazakhstan N. Nazarbayev, who in his work (Nazarbaev, 1992), which was merely the first in the field, outlined the strategy of resource-saving as a fundamental direction of the country's development. The following significant author, Vovk Yurii, in his work (I. Vovk, Y. Vovk, 2017) investigated the specific features of implementing resource-saving measures at machine-building enterprises, the fundamental work on resourcesaving belongs to the authors of the book (Andrushkiv, I. Vovk, Y. Vovk, Palyanitsa, Pogaydak, Stoyko, 2012), in which resource savings are investigated as a kind of economic relations. A number of authors (Andrushkiv, Yermoshenko, Yerokhin, Liashenko, Sotnik) investigated resource conservation in the global or national dimension, or as a component of national policy. A separate interesting study is the work of Kondratenko (Kondratenko, 2010), in which the author explores resource conservation in the context of regional economic systems. The most involved in the study of the issue covered in this article are the works of the authors Starytska and Shcherbak in which resource saving is considered at the level of the agricultural enterprise and the author's monograph, in which the initial data of this study are provided. 


\section{METHODS OF RESEARCH}

The problem can be solved on the basis of the use of the dialectical method, which studies the most general connections of the system «nature - society» and the contradictions of these links, as well as the application of the evolutionary approach - gradual development, which is based on continuous, gradual quantitative change as one of the forms of movement in nature and society. Economic-mathematical modeling, that is, the construction of interrelated models, formalizes the resource-saving development of the entire agroindustrial complex, is an effective tool for the rationale of resource-saving innovative projects. The complex of such resource-saving models is an interrelated system of models describing various aspects of the resource-saving functioning of the agrarian economy and is aimed at solving a set of organizational, economic, technical-technological and socioenvironmental problems. The methodological essence of the proposed approach is finding the optimal balance between the resources spent for the implementation of the project (land, water, labor, material, energy, financial, etc.), quality characteristics of products or services (gluten and protein content in the grain, sugar content of beets, fatness of livestock, grade of meat etc.), ecological safety of this project and its ability to reproduce the resource potential. The result of this search is often at the design stage provides significant resource savings.

\section{RESEARCH RESULTS}

According to the author's concept of the approach, the implementation of the resourcesaving strategy with the stimulating role of the state must be implemented in all the main areas at the same time:

- a radical improvement of tax, credit, monetary, customs and tariff policies, investment policy with the aim of creating and maintaining mutually beneficial cooperation between the state and agribusiness, forming prerequisites for sustainable growth of the agrarian economy, protecting domestic agricultural producers and the domestic market of agricultural products;

- changing the role and forms of direct economic regulation with a view to more closely linking the interests of different levels and business entities;

- improvement of the legislative policy aimed at creating a single and more or less stable legal space;

- development of state entrepreneurship in the agrarian sphere with the aim of directly influencing the state to manage agricultural enterprises, first of all they form the scientific and technological potential of the agrarian sector.

By its very nature, the agrarian economy is a socially-oriented market economy and, consequently, is the best conductor of the state policy of social and economic policy. The degree of development and the level of agricultural efficiency largely depend on the balance of the economy as a whole, the state budget and the budget of households. At the same time, agriculture is one of the most resource-intensive industries. The limited volume of natural features of resources (including land and biological potential) to meet the ever growing needs of society in agricultural production through increased production should be considered primarily in the choice of the direction of intensification of agricultural production. Another important feature of agriculture that can't be ignored in the formation of a resourcesaving strategy, due to the specific nature of its transition to a resource-saving type of reproduction, is the fact that under the influence of the scientific and technological revolution 
and the deepening of the social division of labor in agriculture integrated with the supply of industries and spheres. The development of this progressive process of increasing the integration of agricultural production has led to the emergence of a qualitatively new subsystem of the economy - agriculture, covering all stages of the production of food products from the means of production for agricultural enterprises, the production of agricultural raw materials, processing and processing and bringing it to the consumer. Single attempts to reform the agro-industrial sector led to the destruction of the agro-industrial complex as an integrated system. Without restoration of its integrity, sustainable economic growth is impossible, therefore part of the resource-saving strategy should be focused on its restoration. Summarizing the results of management and economic science based on specific features of agricultural enterprises, let's propose the following effective resource-saving strategy for agricultural enterprises in the Poltava region (Fig. 1), which was adapted from previous author`s work in this journal (Gerasymchuk, 2013).

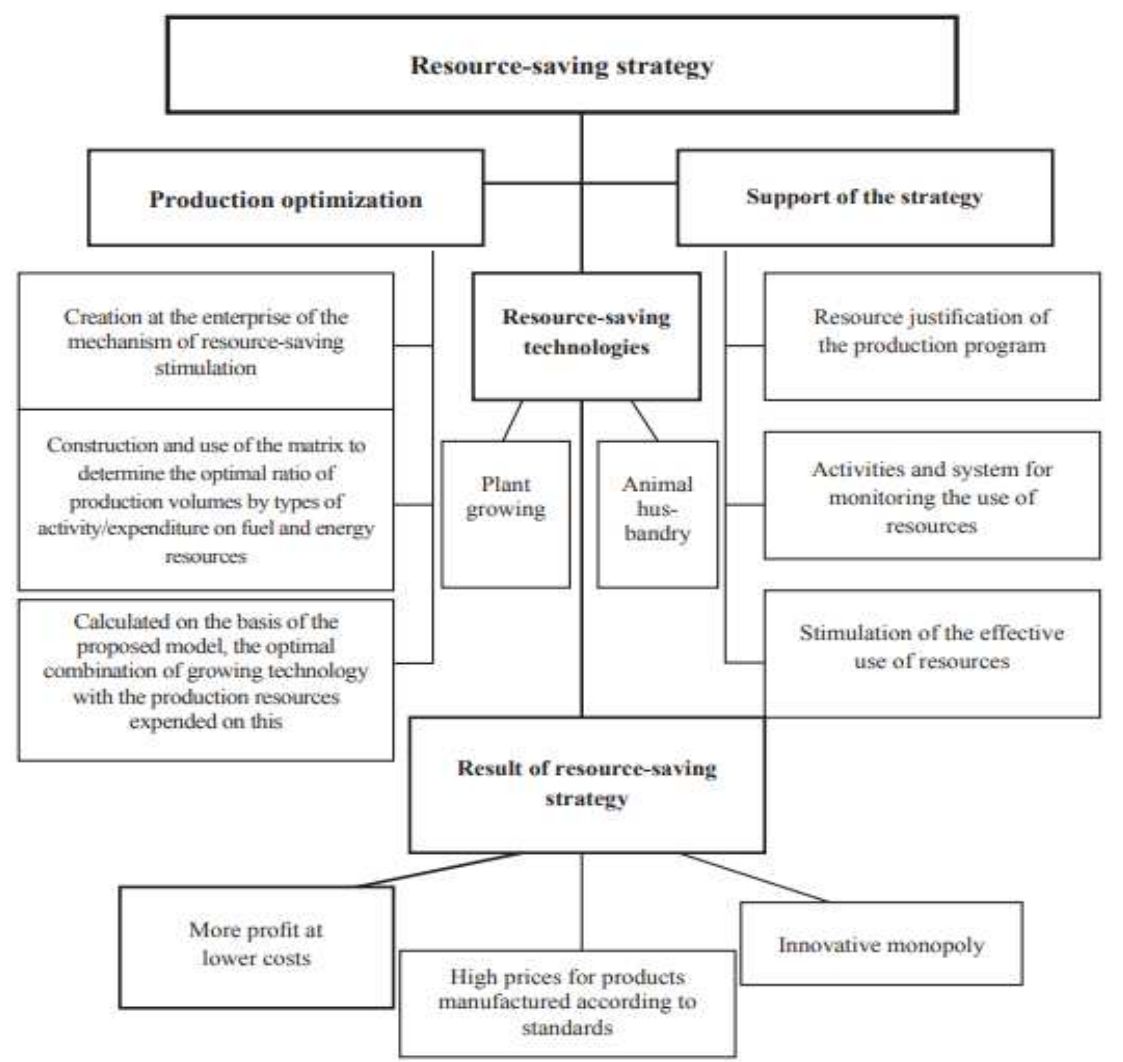

Figure 1. The concept of a resource-saving strategy in the economic activities of agricultural enterprises

Source: own work.

The main idea of most of the individual measures proposed in our strategy is stimulation of the necessary behavior, leaving the details of individual events open and not making 
them mandatory. Thus, existing market mechanisms are unlikely to be violated. Under the laws of the open market there should be no restrictions on entrepreneurial freedom, therefore the issue of the effectiveness of resource use should be spread by raising the awareness level and be integrated into the competencies and skills profiles of entrepreneurs (Urban, 2010). In addition, environmental and/or resource-saving technologies are a derivative of the development of innovative and research processes of the enterprise that arise as part of a global movement towards sustainable agriculture (Garcia-Torres, 2003). The strategy considers three synergetic components of the agro-industrial complex development (Gerasymchuk, 2015):

- Production efficiency: optimization of the productive use of natural resources (materials, energy and water).

- Environmental management: minimizing the impact on the environment and nature by reducing waste and emissions.

- Human development: minimizing risks for people and communities, and supporting their development.

Achieving the goal of the resource-saving strategy is carried out in the production process through the use of innovative activity, the latest technologies, better process control and entrepreneurial incentives. The environmental part of the resource-saving strategy includes the following activities: monitoring of the consumption of water and wastewater generation by taking into account all sources of use and discharge points; development of key performance indicators and level of monitoring performance; improvement of agricultural activities; manure processing with the study of the possibility of methane capture for heating, control of efficiency and establishment of a preventive maintenance program to control leaks, straits and overflows. In the process of public discussion of the Poltava Development Strategy for the period until 2020, we proposed a resource-saving strategy in the form of its specific implementation areas, in accordance with operational objective 2.3. «Ensuring energy security, forming energy-efficient public, agrarian and industrial sectors» and 2.2. «Strengthening small and medium-sized enterprises (SMEs)», depicted in Fig. 2.

The studies conducted in one of the enterprises prove the possibility of obtaining an equivalent substitute for mineral fertilizers from manure using biotechnology. The introduction of resource-saving technology of direct sowing of spring wheat with the introduction of biofertilizers provides a reduction in the cost per 1 hectare for the amount of 999.6 UAH compared with intensive, and the specific costs of work are reduced by 2.3 times, fuel - 1.7 times, mineral fertilizers -3.7 and protective equipment -3 times (approved in Semenovska district of the Poltava region). In general, due to the transition to resource-saving technologies, the cost of 1 ton of grain is reduced by $35 \%$ and with an average annual sowing area of spring cereals in the region of about 832.7 thousand ha, the resource-saving effect will be 832 million UAH. In addition, there is a reduction in soil erosion and an increase in its fertility

In animal husbandry, the priority direction of resource conservation is the transition to efficient feed production technologies and new optimized feeding rations that allow to increase productivity while reducing the unit cost of resources. The transition to energy saving technologies, the creation of an optimal microclimate in the cultivation of animals, can reduce energy costs by $35 \%$, and the use of bioenergy plants for the utilization of manure in biogas - to provide its own autonomous power supply of both livestock complex and other divisions of the economy. 


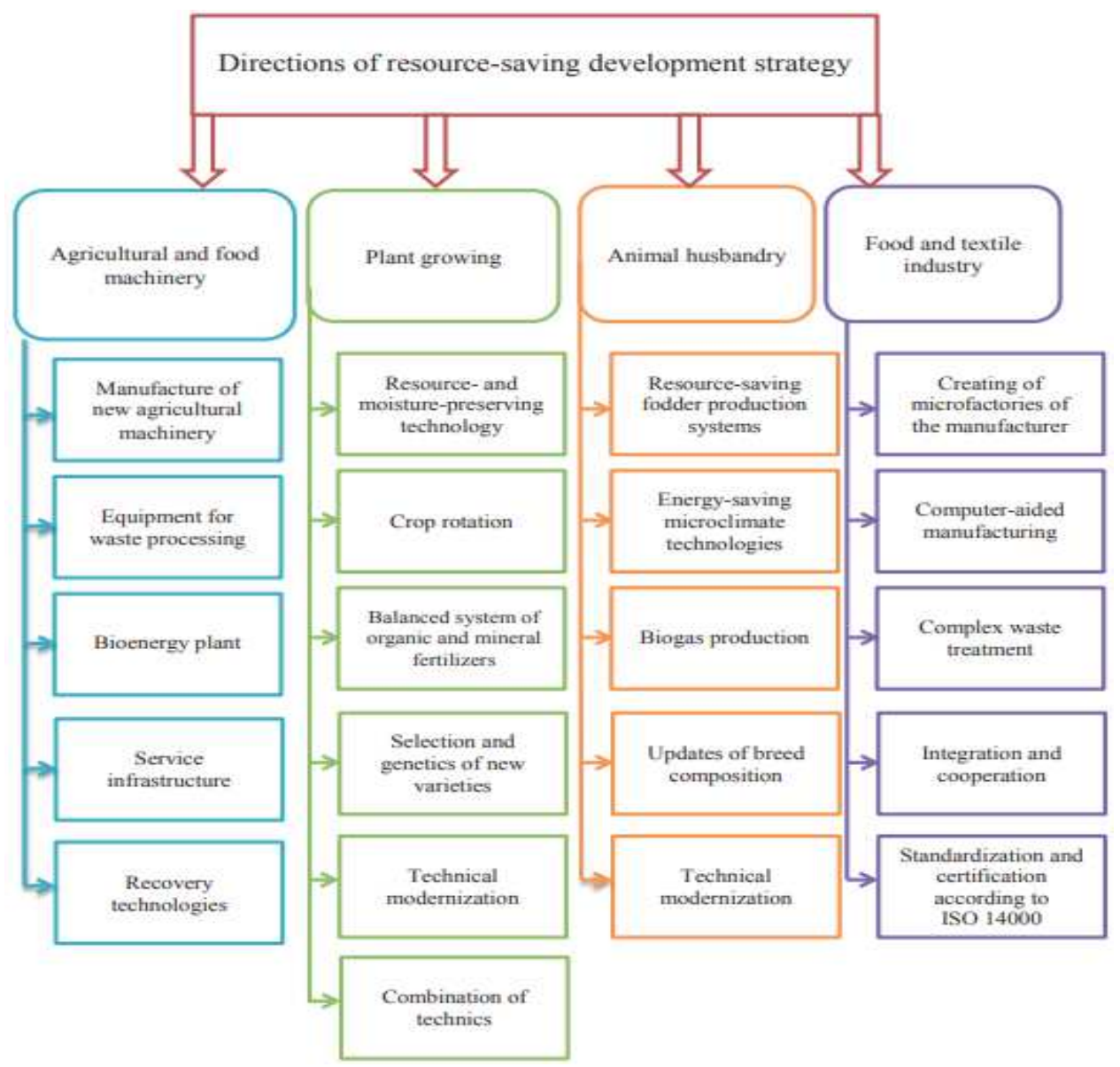

Figure 2. Proposed directions of resource-saving development

Source: own work.

The bioenergy plant allows to receive energy by $70 \%$ cheaper than that of external suppliers. As a result, due to a complex of resource-saving measures, the cost of pork is reduced by $29 \%$. The solution of the problem of effective processing of manure in biogas or biofertilizer has a special economic significance.

In the meat industry, the priority of resource-saving development remains complex processing of waste and optimization of the recipes for meat and sausage products. The organization of specialized meat-processing production provides an opportunity for deep processing of food and non-food waste. Resource-saving technology is the development of fodder flour and fat from non-food waste from slaughtering cattle, but even more potential for resourcesaving is laid in the use of secondary raw materials for therapeutic and preventive purposes. The introduction of an optimized multi-component recipe for sausages makes it possible to reduce the cost of products by $18 \%$ while maintaining their quality characteristics (according to the Globin Meat-Processing Plant). In the dairy industry, it is possible 
to achieve a high level of resource saving through reasonable concentration and modernization of the material and technical base.

Thus, in the production of butter, the least energy-intensive and capital-intensive technology product by $12 \%$ and improve its quality characteristics. It is effective to use the dairy products (primarily buttermilk and whey) for the production of sour milk drinks, it allows storing whole milk and using the secondary raw materials with maximum efficiency. The cost price of a sour-milk drink in this case is $30 \%$ lower than in traditional technology. Great prospects also have new energy-saving technologies for pasteurizing milk, reducing energy costs by $79 \%$. In the milling industry, the resource saving resource is primarily the technology of flour production and the level of waste-free production. Optimization of technological regimes and minimization of losses makes it possible to reduce the resource intensity of flour-milling production by $10-12 \%$ (tested in «Yana» LLC, Svitlovodsk District, Kyrovograd Region). An indispensable condition for куыщгксу saving is also based on the concentration of the industry and the uniform loading of technological equipment. Domestic bakery production is characterized by very high energy intensity and due to the modernization of furnaces, as well as optimization of the multicomponent baking bread recipe, it is possible to reduce its cost by $12 \%$.

\section{CONCLUSIONS}

1. Development of resource-saving processes in the agro-industrial complex will be facilitated by the creation, at various levels of government, of bodies coordinating issues of resource provision and resource saving. It includes an information-analytical group (employees of the economic service of the enterprise) and a sector of resource-saving projects. With the efforts of this service, effective measures are taken to switch to non-waste technologies for production of high-quality rye flour and to justify the resource-saving indicators of installed equipment, and innovative business projects are developed for the further development of the material and technical base of the processing industry created on the basis of this enterprise for further processing of products.

2. The proposals on resource-saving projects and improvement of the state structure of resource-saving management have already been reflected in the regional program for the development of the agro-industrial complex in the Poltava region.

3. Summarizing the above, it should be noted that due to a complex of organizational, economic and technicaltechnological projects, it is possible to dynamically develop the resource-saving potential of the regional agro-industrial complex. Further activities in this direction will lead to formation and effective functioning of a resourcesaving mechanism for development of the agro-industrial complex.

\section{REFERENCES}

Andrieieva, N., Barun, M. (2014). Resursozberihaiucha skladova yak aspekt ekolohizatsii vyrobnytstva. "Ekonomichni innovatsii", Vol. 57.

Andrushkiv, B., Vovk, Yu., Pohaidak, O. et al. (2012). Resursonomika: teoretychni ta prykladni aspekty. Ternopil: TzOV «Terno-hraf».

Garcia-Torres, L., Benites, J., Martinez-Vilela, A., Holgado-Cabrera, A. (2003). Conservation Agriculture. Springer Science+Business Media B.V. 
Gerasymchuk, N. (2009). Rural enterpreneurship development by means of organization of cooperation between small agricultural and agrotourist. „Actual Problems of Economics”, No. 9 (99).

Gerasymchuk, N.A. (2015). Pidpryiemnytskyi mekhanizm resursozberihaiuchoho rozvytku APK. Kyiv: TsP «Komprint».

Kondratenko, N. (2010). Stratehiia resursozberezhennia rehionalnykh ekonomichnykh system. Kharkiv: NTM.

Kubatko, O, Iskakov, A. (2017). The Concept of Resource Conservation in the Context of Providing Ecological and Economic Security of the National Economy. "Mechanism of Economic Regulation", No 4.

Liashenko, I. (2012). Specifics and perspectives of resource saving in Ukraine. „Efektyvna ekonomika".

Nazarbaev, N. (1992). Strategiya resursosberezheniya i perekhod k rynku. Moscow: Mashinostroenie.

Shcherbak, V. (2016). Resource saving as a priority trend in the development of agrarian entrepreneurial potential. „Actual problems of economics” (181).

Sotnyk, I. (2006). Resursozberezhennia ta ekonomichnyi rozvytok Ukrainy. Formuvannia mekhanizmiv perekhodu sub'iektiv gospodariuvannia Ukrainy do ekonomichnogo rozvytku na bazi resursozberihaiuchykh tekhnologii. Sumy: Universytetska knyga.

Starytska, O. (2005). Resursozberezhennia $v$ systemi ekonomichnoho mekhanizmu pidvyshchennia efektyvnosti silskohospodarskoho vyrobnytstva. Naukovi zapysky TDPU im. V. Hnatiuka. Seriia: Ekonomika, 18.

Urban, B. (2010) Frontiers in Entrepreneurship. Berlin: Heidelberg: Springer-Verlag.

Vovk, I. (2012). Features of resource conservation measures and methods of their effectiveness in engineering enterprises in the context of resourcenomy. „Visnyk Sumskoho derzhavnoho universytetu". Seriia: Ekonomika, 4.

Yermoshenko, M., Hanushchak-Iefimenko, L. (2010). Mekhanizm rozvytku innovatsiinoho potentsialu klasteroobiednanykh pidpryiemstv. Kyiv: Natsionalna Akademiia Upravlinnia.

Yerokhin, S.A. (2002). Strukturna transformatsiia natsionalnoi ekonomiky (teoretykometodolohichnyi aspekt). Kyiv: Svit Znan.

Zaburanna, L., Gerasymchuk, N. (2014). Optimization of agriculture production on the basis of resource saving strategy. „Modern Management Review”, No. 2.

Zhao, Q., Huang, J. (2011). Roadmap of Resource Saving Agricultural Science and Technology Development. Agricultural Science \& Technology in China: A Roadmap to 2050.

DOI: $10.7862 /$ rz.2019.mmr.26

The text was submitted to the editorial office: December 2019.

The text was accepted for publication: January 2020. 